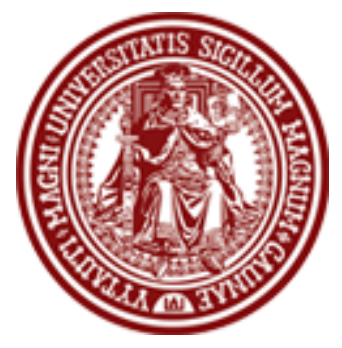

BALTIC JOURNAL OF LAW \& POLITICS

VOLUME 4, NUMBER 1 (2011)

ISSN 2029-0454

http://www.versita.com/bjlp

Cit.: Baltic Journal of Law \& Politics 4:1 (2011): 134-153

DOI: $10.2478 / \mathrm{v} 10076-011-0006-3$

\title{
THE DEVELOPMENT OF EUROPEAN CRIMINAL LAW AS A CULTURAL CHALLENGE
}

\author{
Volker Stiebig \\ Assistant Lecturer; Dr. iur. \\ Justus-Liebig-University Giessen, Faculty of Law (Germany) \\ Contact information \\ Address: Licher Strasse 60, 35394 Giessen, Germany \\ Phone: +496419921104 \\ E-mail address: Volker.Stiebig@recht.uni-giessen.de
}

Received: May 16, 2011; reviews: 2; accepted: July 20, 2011.

\section{ABSTRACT}

The article gives an appraisal of the last years' development in criminal matters in the European Union and answers the question if an integrative "European Criminal Law" already exists. Against this background, the "Lisbon Judgment" of the Federal Constitutional Court is analyzed and the basic guidelines of the judgment regarding criminal law are elaborated. The article also explains the requirements made by the Federal Constitutional Court on the decisions on punishable behavior, on the rank of legally protected interests and on the meaning of threat of punishment. Based on this, the additional value of a supranational public prosecution is discussed, as well as some ways in which criminal law influences the cultural identity of European nations.

\section{KEYWORDS}

Constitution for Europe, cultural identity, European criminal law, European integration, German Constitution, Lisbon Judgment, Lisbon Treaty 


\section{INTRODUCTION}

According to Article 3, paragraph 2 TEU (post-Lisbon version), Article 67, paragraph 1 TFEU, the European Union shall constitute an area of freedom, security and justice with respect for fundamental rights and the different legal systems and traditions of the member states. ${ }^{1}$ Article 67 , paragraph 3 TFEU provides that:

The Union shall endeavour to ensure a high level of security through measures to prevent and combat crime, racism and xenophobia, and through measures for coordination and cooperation between police and judicial authorities and other competent authorities, as well as through the mutual recognition of judgments in criminal matters and, if necessary, through the approximation of criminal laws.

Criminal law is important for achieving this aim, because criminal action may destroy the lives of victims, and criminal sanctions have a strong influence on personal living conditions. ${ }^{2}$ Criminal law serves as an instrument to save social values and mirrors the socio-cultural and historic-traditional diversity of nations which, under the sixth sentence of paragraph 3 of Article 3 TEU (post-Lisbon version), shall be respected by the European Union. ${ }^{3}$ Furthermore, criminal law balances public and individual interests. ${ }^{4}$ The impact of criminal law is the same not

${ }^{1}$ Cf. Bernd Hecker, "Der Vertrag von Lissabon und das Europäische Strafrecht" (The Lisbon Treaty and European Criminal Law), Iurratio 2/2009: 82 // http://www.iurratio.de/zeitschrift/ausgabe-22009/100 (accessed December 20, 2010); Volker Stiebig, Vollstreckungsverzicht und Grundfreiheiten (Desisting from enforcement and fundamental freedoms) (Frankfurt a.M.: Lang, 2003), pp. 1-2.

${ }^{2}$ Cf. BVerfGE (decisions of the Federal Constitutional Court, Vol.) 123, pp. 408, $413=$ Neue Juristische Wochenschrift (New legal weekly paper).. (NJW) 31/2009: 2287, paragraph 355; 2289, paragraph 365; Kai Ambos and Peter Rackow, "Erste Überlegungen zu den Konsequenzen des Lissabon-Urteils des Bundesverfassungsgerichts für das Europäische Strafrecht" (First considerations on the consequences of the Lisbon Judgment of the Federal Constitutional Court for European Criminal Law), Zeitschrift für Internationale Strafrechtsdogmatik (Journal of international criminal law dogmatics) (ZIS) 8-9/2009: 399, 405 // http://www.zis-online.com/dat/artikel/2009_8-9_346.pdf (accessed December 20, 2010); q.v. Stefan Braum, "Europäisches Strafrecht im Fokus konfligierender Verfassungsmodelle. Stoppt das Bundesverfassungsgericht die europäische Strafrechtsentwicklung?" (European criminal law in the focus of conflicting constitutional systems. Will the Federal Constitutional Court stop the European development in criminal law matters?), Zeitschrift für Internationale Strafrechtsdogmatik (Journal of international criminal law dogmatics) (ZIS) 8-9/2009: 423 //

http://www.zis-online.com/dat/artikel/2009_8-9_348.pdf (accessed December 20, 2010).

3 Cf. Helmut Satzger, Die Europäisierung des Strafrechts. Eine Untersuchung zum Einfluss des Europäischen Gemeinschaftsrechts auf das deutsche Strafrecht (The Europeanization of criminal law. A study of the impact of the European Community law on German criminal law) (Köln: Carl Heymanns, 2001), pp. 159-165; q.v. BVerfGE (Decisions of the Federal Constitutional Court, Vol.) 123, pp. 359-360 = Neue Juristische Wochenschrift (New legal weekly paper) (NJW) 31/2009: 2274, paragraph 253; Hans-Peter Folz, "Karlsruhe, Lissabon und das Strafrecht - ein Blick über den Zaun" (Karlsruhe, Lisbon and criminal law - getting an impression of the Federal Constitutional Court's jurisdiction), Zeitschrift für Internationale Strafrechtsdogmatik (Journal of international criminal law dogmatics) (ZIS) 8-9/2009: 427-428 // http://www.zis-online.com/dat/artikel/2009_8-9_349.pdf (accessed December 20, 2010); Jesús-María Silva Sánchez, Die Expansion des Strafrechts. Kriminalpolitik in postindustriellen Gesellschaften (The expansion of criminal law. Criminal policy in post-industrial societies) (Frankfurt a.M.: Vittorio Klostermann, 2003).

${ }^{4}$ Mark A. Zöller, "Europäische Strafgesetzgebung" (European criminal law legislation), Zeitschrift für Internationale Strafrechtsdogmatik (Journal of international criminal law dogmatics) (ZIS) 7/2009: 349 // http://www.zis-online.com/dat/artikel/2009_7_335.pdf (accessed December 20, 2010). 
only in all of Europe but in all the countries of the world. Criminal law, in this respect, officiates as an instrument of European integration policy. ${ }^{5}$

In comparison to other fields of EU policy, criminal law had played a rather inferior role until the end of the 1990s, not least because of national skepticism towards European influence. ${ }^{6}$ From the consistent case-law of the European Court of Justice, every legal act of the European Union needs a clear and unambiguous legal basis because of the parliamentary prerogative in the field of criminal law. ${ }^{7}$ Thus, criminal law remained a nucleus of national sovereignty for a long time. ${ }^{8}$ Meanwhile, criminal law more and more has been focused on the European scale because of a fast-paced progression of crime rates. ${ }^{9}$ The Lisbon Treaty provides for the broader participation of national parliaments in the police and judicial cooperation in criminal matters. ${ }^{10}$ In lieu of the ratification of conventions pursuant to ex Article 34, paragraph 2(d) TEU, national parliaments now ensure that the proposals and legislative initiatives concerning the police and judicial cooperation in

5 Stefan Braum, "Europäisches Strafrecht im administrativen Rechtsstil. Zur kriminalpolitischen Konzeption des EU-Grünbuchs Europäische Staatsanwaltschaft" (European criminal law in an administrative style of making and applying law. On the crimino-political conception of the Green Paper "European Public Prosecutor's Office"), Zeitschrift für Rechtspolitik (Journal of legal policy) (ZRP) 12/2002: 508; Bernd Hecker, supra note 1: 82; Volker Stiebig, "Strafrechtsetzungskompetenz der Europäischen Gemeinschaft und Europäisches Strafrecht: Skylla und Charybdis einer europäischen Odyssee?" (The European Community's competence of making criminal law and European Criminal Law: Skylla and Charybdis of a European odyssey?), Europarecht (European law) (EuR) 4/2005: 467, 492 // http://www.europarecht.nomos.de/fileadmin/eur/doc/EuR_05_04.pdf (accessed December 20, 2010); Mark A. Zöller, supra note 4: 349; Manfred Zuleeg, "Der Beitrag des Strafrechts zur Europäischen Integration" (The contribution of criminal law to European integration): 58; in: Ulrich Sieber, ed., Europäische Einigung und Europäisches Strafrecht. Beiträge zum Gründungssymposium der Vereinigung für Europäisches Strafrecht e.V. (European unification and European Criminal Law. Papers written on the occasion of the symposium to celebrate the foundation of the incorporated Association for European Law) (Köln, Berlin, Bonn, München: Carl Heymanns, 1993).

${ }^{6}$ See, for Germany, e.g. Volker Stiebig, supra note 5: 466-467; Oliver Suhr, "Strafrechtsharmonisierung in der Europäischen Union. Neue Grenzziehungen und zusätzliche Kontrollaufträge" (Approximation of criminal laws in the European Union. New delineations and additional mandates for scrutiny), Zeitschrift für europarechtliche Studien (Journal of European law studies) (ZEuS) 1/2008: 46-48 (48: from the sight of European law drastic at times); Frank Zieschang, "Der Einfluss der Europäischen Union auf das deutsche Strafrecht - Eine Bestandsaufnahme -" (The impact of the European Union on German criminal law - An appraisal -): 1303; in: Ulrich Sieber et al., eds., Strafrecht und Wirtschaftsstrafrecht Dogmatik, Rechtsvergleich, Rechtstatsachen -. Festschrift für Klaus Tiedemann zum 70. Geburtstag (Criminal law and law relating to economic offenses - dogmatics, comparative law analysis, legal facts -. Festschrift for Klaus Tiedemann on the occasion of his $70^{\text {th }}$ birthday) (Köln, Berlin, Bonn, München: Carl Heymanns, 2008); q.v. Bernd Hecker, Europäisches Strafrecht (European criminal law) (Heidelberg: Springer, 2010), §1, marginal numbers 12-13, 37.

7 See, for references, Volker Stiebig, supra note 1, p. 9, note 47; Mark A. Zöller, supra note 4: 343, 344-346; concerning the legal status before the Lisbon Treaty came into force, see Bernd Hecker, supra note 1: 82; Volker Stiebig, l.c., p. 9; Oliver Suhr, supra note 6: 48-63.

${ }^{8}$ See Volker Stiebig, supra note 1, p. 9, with further references.

${ }^{9}$ Cf. Bernd Hecker, supra note 1: 83; idem, supra note 6 , 1 , marginal number 11; Volker Stiebig, supra note 5: 475-476, 477-479, 490-492; q.v. Helmut Satzger, Internationales und Europäisches Strafrecht. Strafanwendungsrecht/Europäisches Straf- und Strafverfahrensrecht/Völkerstrafrecht (International and European criminal law. Law regulating the implementation of penalty/European substantive and procedural criminal law/international criminal law) (Baden-Baden: Nomos, 2010), § 7, marginal numbers 4-8; Jesús-María Silva Sánchez, supra note 3.

${ }_{10}$ See, for details, Bernd Hecker, supra note 1: 82-85; Oliver Suhr, supra note 6: 63-66. Concerning the Treaty establishing a Constitution for Europe which has not been ratified by all of the member states, see Bernd Hecker, I.c.: 81; Volker Stiebig, supra note 1, pp. 37-38; idem, supra note 5: 475, 480, 487489, 492-493; Frank Zieschang, supra note 6: 1308-1309, 1313-1314, 1317; Mark A. Zöller, supra note $4: 343-344,347$. 
criminal matters comply with the principle of subsidiarity (Article 69 TFEU). ${ }^{11}$ Furthermore, the national parliaments are involved in the regulation of the procedures for scrutiny and in the evaluation of Eurojust's activities (Articles 70, 85, 88 TFEU). ${ }^{12}$ Whether the Treaty allows the Union an original law-making competence (Article 79, paragraph 2 and Article 325 TFEU) has been controversial. ${ }^{13}$ By all means, the Treaty allows an approximation of substantive and procedural criminal laws ${ }^{14}$ and sanctions the Charter of Fundamental Rights of the European Union. ${ }^{15}$ Nevertheless, a supranational doctrine of criminal action ${ }^{16}$ as a basis for European unification - is still missing. ${ }^{17}$ In fact, two different levels of criminal law action have been developed: a national level, where mainly the punitive function of criminal law comes to the fore, and at a supranational level, a Netzwerk-Strafrecht (criminal law network) granting social control. ${ }^{18}$ At the supranational level, a successful cooperation between the member states' law enforcement authorities has existed in the past, so that one may ask what additional value is really offered by supranational competences in the field of

${ }^{11}$ See Oliver Suhr, supra note 6: 63.

12 Ibid.: 63.

13 Martin Heger, "Perspektiven des Europäischen Strafrechts nach dem Vertrag von Lissabon. Eine Durchsicht des (wohl) kommenden EU-Primärrechts vor dem Hintergrund des Lissabon-Urteils des BVerfG vom 30.6.2009" (Perspectives of European Criminal Law pursuant to the Lisbon Treaty. A review of the (probably) coming EU primary law against the background of the Lisbon Judgment of the Federal Constitutional Court issued on June 30, 2009), Zeitschrift für Internationale Strafrechtsdogmatik (Journal of international criminal law dogmatics) (ZIS) 8-9/2009: 415 // http://www.zisonline.com/dat/artikel/2009_8-9_347.pdf (accessed December 20, 2010); Frank Zieschang, supra note 6: 1313-1314; vide infra section 2.1.

${ }^{14}$ See, for details, Oliver Suhr, supra note 6: 65-66; q.v. Pierre Hauck, "Funktionen und Grenzen des Einflusses der Strafrechtsvergleichung auf die Strafrechtsharmonisierung in der Europäischen Union" (Functions and limitations of the impact of comparative criminal law on the approximation of laws in the European Union): 255-273; in: Susanne Beck et al., eds., Strafrechtsvergleichung als Problem und Lösung. Kolloquium am 30. und 31. Oktober 2009 an der Juristischen Fakultät der Julius-MaximiliansUniversität Würzburg (Comparative criminal law both as problem and as solution. Congress on October 30 and 31, 2009 at the faculty of law of the Julius-Maximilians-University Würzburg) (Baden-Baden: Nomos, 2010); Bernd Hecker, supra note 1: 82-85; idem, supra note 6, § 1, marginal number 36, §§ 8, 11; Helmut Satzger, supra note 9, § 9, marginal numbers 31-53, § 10, marginal numbers 51-61.

${ }_{15}$ Martin Heger, supra note 13: 408; concerning the Charter of Fundamental Rights (http://eurlex.europa.eu/LexUriServ/LexUriServ.do?uri=OJ:C:2010:083:0389:0403:EN:PDF; accessed December 20, 2010), q.v. Volker Stiebig, supra note 1, pp. 64-65, with further references.

${ }_{16}$ See Manuel Cancio Meliá, "Rechtsvergleichende Bemerkungen zum Allgemeinen Teil des portugiesischen Strafgesetzbuchs aus spanisch-deutscher Sicht" (Comparative law comments on the general part of the Portuguese criminal code from a Spanish-German view), Goltdammer's Archiv für Strafrecht (Goltdammer's archive of criminal law) (GA) 3/1998: 118-123; Stefano Manacorda, "Die allgemeine Lehre von der Straftat in Frankreich: Besonderheiten oder Lücken in der französischen Strafrechtswissenschaft?" (The general doctrine of criminal action in France: specific characteristics or desideratums in French penologic science?), l.c.: 124-126; Carlos Suárez González, "Rechtsvergleichende Bemerkungen zum Allgemeinen Teil des neuen spanischen Strafgesetzbuches" (Comparative law comments on the general part of the new Spanish criminal code), l.c.: 111-117; Klaus Tiedemann, "Lehren von der Straftat im Allgemeinen Teil der Europäischen Rechtssysteme Überlegungen zur Strafrechtsangleichung in Europa -/Einleitung: Re-Europäisierung des Strafrechts versus Nationalismus der (deutschen) Strafrechtslehre" (Doctrines of criminal action in the general part of European legal systems - considerations on the approximation of criminal laws in Europe -l Introduction: Re-Europeanization of criminal law versus nationalism of (German) criminal law dogmatics), I.c.: 107-110; Joachim Vogel, "Elemente der Straftat: Bemerkungen zur französischen Straftatlehre und zur Straftatlehre des common law" (Elements of criminal action: comments on the French doctrine of criminal action and on the common law doctrine of criminal action), l.c.: 127-150.

17 See, for details, Volker Stiebig, supra note 1, p. 6.

18 Vide infra section 1. 
criminal law. ${ }^{19}$ The last years' experiences have shown that the cultural diversity of European nations demands that action concerning the unification process should not be too hastily taken. ${ }^{20}$ Otherwise, Europeans will not be able to identify with European standards in the future.

Taking into account the Federal Constitutional Court's Lisbon Judgment, this article looks at the status quo of the Europeanization of criminal law from a German point of view and analyzes how lawful conditions may influence the cultural identity of Europeans.

\section{THE LAST YEARS' DEVELOPMENT IN MATTERS OF CRIMINAL LAW IN THE EUROPEAN UNION}

At the present time, criminal law in Germany is informed especially by the European Court of Human Rights' and the European Court of Justice's jurisdiction and their implementation into German criminal justice by the Federal Constitutional Court, the Federal Court of Justice, and penology literature. ${ }^{21}$ It is discussed by jurisdiction and literature on the national level already in what way the European Courts' judgments should be transferred into German law. ${ }^{22}$

Concerning the supranational level, Europe is often ignored in order to enforce national interests. ${ }^{23}$ This leads to the question if an integrative unification on the whole is possible while an integration of Human Rights as a concretizing remedy for

\footnotetext{
${ }^{19}$ Hans-Peter Folz, supra note 3: 427; q.v. Bernd Hecker, supra note $1: 81$.

20 Regarding criminal law, cf. Bernd Hecker, supra note $6, \S 1$, marginal number 37, § 8, marginal number 55; Helmut Satzger, supra note 3, pp. 166-174; idem, supra note 9, § 9, marginal number 9, both authors with reference to the penologic Schonungsgebot (requirement of protection); concurring: Johannes Wessels and Werner Beulke, Strafrecht Allgemeiner Teil. Die Straftat und ihr Aufbau (The general part of criminal law. Criminal action and the way of analyzing it) (Heidelberg: C.F. Müller, 2010), § 2, marginal number 77c, note 102 .

${ }^{21}$ Cf. Oliver Suhr, supra note 6: 46-48.

22 The Gesamtbetrachtung (overall view), e.g., which is applied by the ECHR within the consideration of evidence, is interpreted differently; see Jan Dehne-Niemann, "Nie sollst Du mich befragen' - Zur Behandlung des Rechts zur Konfrontation mitbeschuldigter Belastungszeugen (Art. 6 Abs. 3 lit. d EMRK) durch den BGH. Zugleich Besprechung von BGH 4 StR 461/08 - Beschluss vom 9. Juni 2009, HRRS 2009 Nr. 803 und EGMR HRRS 2009 Nr. 459" ("Never you shall interrogate me" - Upon dealing with the right of confrontation of other accused witnesses of the prosecution (Article 6, paragraph 3(d) ECHR) by the Federal Court of Justice. At the same time a review of the Federal Court of Justice's adjudication issued on June 9, 2009 - 4 StR 461/08 -, HRRS 2009 No. 803 and of ECtHR HRRS 2009 No. 459), OnlineZeitschrift für Höchstrichterliche Rechtsprechung im Strafrecht (Online Journal of high court decisions in criminal law) (HRRS) 4/2010: 192-195 // http://www.hrr-strafrecht.de/hrr/archiv/10-04/hrrs-4-10.pdf (accessed December 20, 2010); q.v. Volker Stiebig, "Annotation of the adjudication of the Federal Court of Justice issued on March 17, 2010 - 2 StR 397/09 -", Juristische Rundschau (Law review) (JR) 2011: 174.

${ }^{23}$ Cf. Cornelius Prittwitz, "Nachgeholte Prolegomena zu einem künftigen Corpus Iuris Criminalis für Europa" (Made up prolegomena on a future Corpus Iuris Criminalis for Europe), Zeitschrift für die gesamte Strafrechtswissenschaft (Journal of the whole penologic sciences) (ZStW) 113/4 (2001): 799; Volker Stiebig, supra note 1, p. 5; Klaus Tiedemann, "Die Europäisierung des Strafrechts" (The Europeanization of criminal law): 134; in: Karl F. Kreuzer et al., eds., Die Europäisierung der mitgliedstaatlichen Rechtsordnungen in der Europäischen Union (The Europeanization of the member states' legal systems in the European Union) (Baden-Baden: Nomos, 1997).
} 
interpretation ${ }^{24}$ into national law does not yet work. In this sense it can be asserted that the progress in matters of European criminal law bore a European "NetzwerkStrafrecht" 25 (criminal law network). In the meantime, this has turned out to be a self-ruling apparatus lacking a sufficient legitimation. ${ }^{26}$ In the eyes of the European public, the function of criminal law is noticed less as an instrument of sanctioning than as a provider of social control. ${ }^{27}$ However, its coercive measures are applied rather selectively where assumed to be opportune. ${ }^{28}$ The European citizen often feels helpless in the face of a European legal system detached from national necessities. ${ }^{29}$ European criminal law, therefore, has begun to take on a life of its own especially in the recent past. The reasons for the supranational level removing from the national level are manifold. The principle of conferral $^{30}$ enables national constitutional courts to concede political leeway depending on national requirements. ${ }^{31}$

The scientific discussion of "European Criminal Law" in Germany as a solution for cross-border problems started in the beginning of the 1950s. ${ }^{32}$ In German literature, already in 2002, there was asserted that a European criminal law is taken as a given. ${ }^{33}$ Meanwhile, the process of Europeanization cannot be held back in substantive and procedural criminal law any longer. ${ }^{34}$ In the field of criminal law in the recent past, for instance, foundations have been laid for the implementation of a European Arrest Warrant ${ }^{35}$ and of a European Public Prosecutor's Office. ${ }^{36}$

${ }^{24}$ Ulrich Sommer, "Annotation of the adjudication of the Federal Court of Justice issued on March 17, 2010 - 2 StR 397/09 -", Strafverteidiger Forum (Forum of criminal defence lawyers) (StraFo) 7/2010: $284 ;$ q.v. Volker Stiebig, supra note 22: 175.

${ }^{25}$ Stefan Braum, supra note 2: 420.

${ }^{26}$ Ibid.: 420, 424; differing: Martin Böse, "Die Entscheidung des Bundesverfassungsgerichts zum Vertrag von Lissabon und ihre Bedeutung für die Europäisierung des Strafrechts" (The Federal Constitutional Court's Judgment towards the Lisbon Treaty and its relevance to the Europeanization of criminal law), Zeitschrift für Internationale Strafrechtsdogmatik (Journal of international criminal law dogmatics) (ZIS) 2/2010: 85 // http://www.zis-online.com/dat/artikel/2010_2_407.pdf (accessed December 20, 2010).

27 Cf. Stefan Braum, supra note 2: 420.

${ }^{28}$ Cf. ibid.

${ }^{29}$ Cf. ibid.

${ }^{30}$ Vide infra section 2.1.

${ }^{31}$ Cf. Stefan Braum, supra note 2: 422.

32 Josef Zila, "Akzeptanz des Europäischen Strafrechts in Schweden" (Acceptance of European Criminal Law in Sweden): 63-64, with further references; in: Gerhard Hohloch, ed., Wege zum Europäischen Recht (Avenues to European law) (Baden-Baden: Nomos, 2002).

${ }^{33}$ Frank Zieschang, "Akzeptanz Europäischen Strafrechts?" (Acceptance of European criminal law?): 50; in: Gerhard Hohloch, ed., Wege zum Europäischen Recht (Avenues to European law) (Baden-Baden: Nomos, 2002); furthermore Stephan Beukelmann, "Europäisierung des Strafrechts - Die neue strafrechtliche Ordnung nach dem Vertrag von Lissabon" (Europeanization of criminal law - the new criminal law order pursuant to the Lisbon Treaty), Neue Juristische Wochenschrift (New legal weekly paper) (NJW) 29/2010: 2081; Bernd Hecker, supra note 1: 81; q.v. Helmut Satzger, supra note 3, pp. 152-156; idem, supra note 9, § 7, marginal numbers 2-3.

${ }^{34}$ See Bernd Hecker, supra note 1: 81; Volker Stiebig, supra note 5: 467-468, 469, 490; Oliver Suhr, supra note 6: 75; Frank Zieschang, supra note 6: 1319 (European criminal law will be established sooner or later); Mark A. Zöller, supra note 4: 340.

35 See Observatório Permanente da Justiça Portuguesa, Centro de Estudos Sociais, Colégio de S. Gerónimo (Permanent committee of the Portuguese justice, centre of social studies, S. Gerónimo College), ed., The European Arrest Warrant in Law and in Practice: A Comparative Study for the Consolidation of the European Law-Enforcement Area (Coimbra: 2010) // http://opj.ces.uc.pt/pdf/EAW_Final_Report_Nov_2010.pdf (accessed December 20, 2010); q.v. Nico Keijzer and Elies Van Sliedregt, eds., The European Arrest Warrant in Practice (Den Haag: T.M.C. Asser 
Modern provocations, such as international terrorism, corruption, and mafia-like structures, still have to be confronted. ${ }^{37}$ Globalization is creating new challenges.

\section{THE "LISBON JUDGMENT" AND ITS CULTURAL IMPACT ON CRIMINAL LAW}

\subsection{THE JUDGMENT}

With its "Lisbon Judgment" issued on June 30, 200938, the Federal Constitutional Court cleared the way for the President of the Federal Republic of Germany to ratify the Lisbon Treaty ${ }^{39}$ and controlled if the Lisbon Treaty respectively the German act of sanctioning - and the implementation into German Law is compatible with German Constitutional Law. In the grounds of the judgment, on the one hand one can even note a constitutional obligation for participation on the part of Germany in European integration ("Europarechtsfreundlichkeit"140). On the other hand, the judgment principally takes up a German position and in this way offers, of course, a certain "Staatszentrierung"41 (focusing on national interests). Because of that, the judgment does not lend itself to correct the deficit of legitimation of the Netzwerk-Strafrecht ${ }^{42}$.

The Lisbon Treaty as such was held to be constitutional by the court. The law passed together with the law of ratification and the constitutional law of amendment has been declared as unconstitutional: with reference to the extension and strengthening of the German Federal Parliament's and the German Federal Council's rights concerning affairs of the European Union, the Constitutional Court

Press, 2009); Arndt Sinn and Liane Wörner, "The European Arrest Warrant and Its Implementation In Germany - Its Constitutionality, Laws and Current Developments", Zeitschrift für Internationale Strafrechtsdogmatik (Journal of international criminal law dogmatics) (ZIS) 5/2007: 204-220 // http://www.zis-online.com/dat/artikel/2007_5_135.pdf (accessed December 20, 2010); Volker Stiebig, supra note 1 , pp. 42-44, with further references.

${ }^{36}$ See Silke Nürnberger, "Die zukünftige Europäische Staatsanwaltschaft - Eine Einführung" (The future European Public Prosecutor's Office - An introduction), Zeitschrift für das Juristische Studium (Journal of law studies) (ZJS) 5/2009: 494-505 // http://www.zjs-online.com/dat/artikel/2009_5_225.pdf (accessed December 20, 2010); Volker Stiebig, supra note 1, pp. 44-48, with further references.

37 Cf. BVerfGE (Decisions of the Federal Constitutional Court, Vol.) 123, p. $410=$ Neue Juristische Wochenschrift (New legal weekly paper) (NJW) 31/2009: 2288, paragraph 359; Bernd Hecker, supra note 1: 81-82; idem, supra note 6 , § 1, marginal numbers 32-34, § 2, marginal number 61 ; Volker Stiebig, supra note 1, pp. 30-56, passim; q.v. Liane Wörner, The Effectiveness of Wiretapping and Electronic Surveillance to Fight against Terrorism. A comparative analysis between the United States and Germany (Baden-Baden: Nomos, 2004).

382 BvE 2, 5/08, 2 BvR 1010, 1022, 1259/08, 182/09 - BVerfGE (Decisions of the Federal Constitutional Court, Vol.) 123, pp. 267-437 = Neue Juristische Wochenschrift (New legal weekly paper) (NJW) 31/2009: 2267-2295.

${ }^{39}$ Cf. Jacques Ziller, "The German Constitutional Court's Friendliness towards European Law. On the Judgment of Bundesverfassungsgericht over the Ratification of the Treaty of Lisbon", European Public Law 16/1 (2010): 56-60.

40 BVerfGE (Decisions of the Federal Constitutional Court, Vol.) 123, p. $347=$ Neue Juristische Wochenschrift (New legal weekly paper) (NJW) 31/2009: 2270, paragraph 225; q.v. Jacques Ziller, supra note 39: 66.

${ }^{41}$ Stefan Braum, supra note 2: 424; q.v. Martin Böse, supra note 26: 85.

42 Stefan Braum, supra note 2: 424; q.v. supra section 1. 
found that the national legislature has to be involved in EU decision-making to a higher degree than provided in this law. ${ }^{43}$ The case has been decided unanimously so that there had to be compromises reached where required. ${ }^{44}$ In this respect, one has to beware of hasty interpretations, ${ }^{45}$ especially because of the difficulty in translating German into English or Romance languages ${ }^{46}$. For the non-German speaker, the Leitsatz practice of the Federal Constitutional Court may cause additional problems in understanding the grounds of the judgment. ${ }^{47}$

The grounds contain, inter alia, explanations which expose the basic importance of substantive and procedural criminal law. The judgment has been discussed as controversial. ${ }^{48}$

The initial point for the Constitutional Court's argumentation is the appraisal that the European Union, even if the Lisbon Treaty comes into force, at its present integration status does not correspond to a standard of legitimation of a constitutional democracy. ${ }^{49}$ The Lisbon Treaty had decided against the idea of a European federal constitution scheduling a European parliament as an organ of representation. ${ }^{50}$ Therefore, the German Federal Parliament - not the government ${ }^{51}$ - took still center stage in an interdependent democratic system. ${ }^{52}$ Being an alliance which possesses legal personality, the European Union, however, had been created by sovereign democratic states. ${ }^{53}$ The present integration status did not require the European institutional system to be organized as an entity modeled on a national state system. ${ }^{54}$

The initial point for the considerations concerning criminal law is the principle of conferral located in the first sentence of the first paragraph and in the second

43 BVerfGE (Decisions of the Federal Constitutional Court, Vol.) 123, p. $432=$ Neue Juristische Wochenschrift (New legal weekly paper) (NJW) 31/2009: 2294, paragraph 406; q.v. Jacques Ziller, supra note 39: 62-63.

${ }^{44}$ Cf. ibid. : 56.

${ }^{45}$ Cf. ibid.

${ }^{46}$ See, for details, ibid.: 57.

47 See, for details, ibid.: 59.

48 Cf., e.g., Kai Ambos and Peter Rackow, supra note 2: 398; Martin Böse, supra note 26: 76; HansPeter Folz, supra note 3: 427, 430-431 (431: approaches concerning criminal law are not the best choice); Philipp Kiiver, "The Lisbon Judgment of the German Constitutional Court: A Court-Ordered Strengthening of the National Legislature in the EU", European Law Journal 16/5 (2010): 578-588 // http://onlinelibrary.wiley.com/doi/10.1111/j.1468-0386.2010.00523.x/pdf (accessed December 20, 2010); Frank Meyer, "Die Lissabon-Entscheidung des BVerfG und das Strafrecht" (The Lisbon Judgment of the Federal Constitutional Court and criminal law), Neue Zeitschrift für Strafrecht (New Journal of criminal law) (NStZ) 12/2009: 657-663.

49 BVerfGE (Decisions of the Federal Constitutional Court, Vol.) 123, p. $370=$ Neue Juristische Wochenschrift (New legal weekly paper) (NJW) 31/2009: 2277, paragraph 276.

50 BVerfGE (Decisions of the Federal Constitutional Court, Vol.) 123, pp. 370-371 = Neue Juristische Wochenschrift (New legal weekly paper) (NJW) 31/2009: 2277, paragraph 277.

51 Jacques Ziller, supra note 39: 65.

52 BVerfGE (Decisions of the Federal Constitutional Court, Vol.) 123, p. $371=$ Neue Juristische Wochenschrift (New legal weekly paper) (NJW) 31/2009: 2277, paragraph 277.

53 BVerfGE (Decisions of the Federal Constitutional Court, Vol.) 123, p. $371=$ Neue Juristische Wochenschrift (New legal weekly paper) (NJW) 31/2009: 2277, paragraph 278.

54 BVerfGE (Decisions of the Federal Constitutional Court, Vol.) 123, p. $371=$ Neue Juristische Wochenschrift (New legal weekly paper) (NJW) 31/2009: 2277, paragraph 278. 
paragraph of Article 5 TEU (post-Lisbon version). ${ }^{55}$ In order to protect principles of democracy, it could become necessary, for the purpose of maintaining the balance of powers between the member states and the Union while distributing sovereignty, to broadly emphasize the principle of conferral in the European treaties and if the treaties are used and interpreted. ${ }^{56}$

Article 5 TEU (post-Lisbon Version) regulates:

(1) The limits of Union competences are governed by the principle of conferral. The use of Union competences is governed by the principles of subsidiarity and proportionality.

(2) Under the principle of conferral, the Union shall act only within the limits of the competences conferred upon it by the Member States in the Treaties to attain the objectives set out therein. Competences not conferred upon the Union in the Treaties remain with the Member States.

Still, the Federal Constitutional Court denies the European Union a Kompetenz-Kompetenz, i.e. the power to determine its own powers. ${ }^{57}$ The German Constitution did not allow the Kompetenz-Kompetenz to be delegated to the Union. ${ }^{58}$ Nevertheless, German constitutional law permitted competences to be conferred to the Union to a large extent. ${ }^{59}$ The act of delegation had to take place in a factually limited manner. ${ }^{60}$ Furthermore, it was necessary that, in principle, it may be cancelled. ${ }^{61}$ For that, the secession of a member state from the European integration system was not to be prevented by other member states or the Union itself. $^{62}$ The principle of conferral, therefore, was not only a European law principle but incorporated principles of the member state constitutions. ${ }^{63}$

Notably important as well for the area of criminal law is Article 83, paragraph 1 TFEU which provides that the European Parliament and the Council, by means of directives, may establish minimum rules concerning the definition of criminal offenses and sanctions in the areas of particularly serious crime with a cross-border

55 BVerfGE (Decisions of the Federal Constitutional Court, Vol.) 123, p. $347=$ Neue Juristische Wochenschrift (New legal weekly paper) (NJW) 31/2009: 2270, paragraph 226; furthermore Stefan Braum, supra note 2: 418, 422-423.

56 BVerfGE (Decisions of the Federal Constitutional Court, Vol.) 123, p. $365=$ Neue Juristische Wochenschrift (New legal weekly paper) (NJW) 31/2009: 2275, paragraph 265.

57 Kai Ambos and Peter Rackow, supra note 2: 404; Philipp Kiiver, supra note 48: 580; q.v. Volker Stiebig, supra note 1 , pp. 36-37.

58 BVerfGE (Decisions of the Federal Constitutional Court, Vol.) 123, p. $349=$ Neue Juristische Wochenschrift (New legal weekly paper) (NJW) 31/2009: 2271, paragraph 233; q.v. Oliver Suhr, supra note 6: 66; Johannes Wessels and Werner Beulke, supra note 20, § 2, marginal number 77c.

59 BVerfGE (Decisions of the Federal Constitutional Court, Vol.) 123, pp. 347-350 = Neue Juristische Wochenschrift (New legal weekly paper) (NJW) 31/2009: 2270, paragraph 226-2271, paragraph 234.

60 BVerfGE (Decisions of the Federal Constitutional Court, Vol.) 123, p. $350=$ Neue Juristische Wochenschrift (New legal weekly paper) (NJW) 31/2009: 2271, paragraph 233.

61 BVerfGE (Decisions of the Federal Constitutional Court, Vol.) 123, p. $350=$ Neue Juristische Wochenschrift (New legal weekly paper) (NJW) 31/2009: 2271, paragraph 233.

62 BVerfGE (Decisions of the Federal Constitutional Court, Vol.) 123, p. $350=$ Neue Juristische Wochenschrift (New legal weekly paper) (NJW) 31/2009: 2271, paragraph 233.

63 BVerfGE (Decisions of the Federal Constitutional Court, Vol.) 123, p. $350=$ Neue Juristische Wochenschrift (New legal weekly paper) (NJW) 31/2009: 2271, paragraph 234. 
dimension. The Council may adopt a decision identifying other areas of crime that meet the criteria specified in this paragraph ${ }^{64}$. It shall act unanimously after having obtained the consent of the European Parliament. ${ }^{65}$

There can be asserted two basic guidelines of the judgment regarding criminal law: 66

(1) Matters of criminal law play a decisive role for democratic selfdetermination.

(2) Criminal law guarantees a minimum of legal ethics.

With respect to the first point, the Federal Constitutional Court considers criminal law as an indispensable device to keep the legal order steadfast. ${ }^{67}$ To which extent and in which fields a political community uses precisely criminal law as an instrument of social control was a decision of fundamental importance. ${ }^{68} \mathrm{~A}$ community based on law, by means of criminal law, created a code of behavior; its violation, in accordance with the common conviction, was considered so serious and so intolerable when living together that it had to be prosecuted. ${ }^{69}$

With regard to the second point, the Constitutional Court refers to the sensitiveness of democratic self-determination concerning matters of criminal law. ${ }^{70}$ This becomes apparent by Article 82, paragraphs 1 and 2 and Article 83, paragraphs 1 and 2 TFEU. These prescriptions provide only a minimum of approximation in the fields of procedural criminal law (Article 82 TFEU) ${ }^{71}$ and substantive criminal law (Article 83 TFEU) ${ }^{72}$.

The utilization of criminal law instruments requires a special justification. ${ }^{73}$ That Article 82, paragraphs 1 and 2 and Article 83, paragraphs 1 and 2 TFEU have to be construed restrictively is proven by the "emergency brake" (Notbremse) ${ }^{74}$ in Article 82, paragraph 3 and in Article 83, paragraph 3 TFEU: ${ }^{75}$

\footnotetext{
${ }^{64}$ For it - from a German point of view - Martin Heger, supra note 13: 414-415.

65 For it ibid. : 411-412.

66 See, for details, e.g. Kai Ambos and Peter Rackow, supra note 2: 397-405; Stephan Beukelmann, supra note 33: 2082-2083; Philipp Kiiver, supra note 48: 578-588; Jacques Ziller, supra note 39: 5660.

67 BVerfGE (Decisions of the Federal Constitutional Court, Vol.) 123, p. $408=$ Neue Juristische Wochenschrift (New legal weekly paper) (NJW) 31/2009: 2287, paragraph 355.

68 BVerfGE (Decisions of the Federal Constitutional Court, Vol.) 123, p. $408=$ Neue Juristische Wochenschrift (New legal weekly paper) (NJW) 31/2009: 2287, paragraph 355.

69 BVerfGE (Decisions of the Federal Constitutional Court, Vol.) 123, p. $408=$ Neue Juristische Wochenschrift (New legal weekly paper) (NJW) 31/2009: 2287, paragraph 355.

70 BVerfGE (Decisions of the Federal Constitutional Court, Vol.) 123, p. $410=$ Neue Juristische Wochenschrift (New legal weekly paper) (NJW) 31/2009: 2288, paragraph 358.

71 See Martin Heger, supra note 13: 411.

72 See Bernd Hecker, supra note 1: 84; Martin Heger, supra note 13: 411-413.

73 BVerfGE (Decisions of the Federal Constitutional Court, Vol.) 123, p. $410=$ Neue Juristische Wochenschrift (New legal weekly paper) (NJW) 31/2009: 2288, paragraph 358.

74 For it Martin Heger, supra note 13: 411, 413-415; Helmut Satzger, supra note 9, § 9, marginal numbers 46-49, each author with examples.

75 BVerfGE (Decisions of the Federal Constitutional Court, Vol.) 123, pp. 410-411 = Neue Juristische Wochenschrift (New legal weekly paper) (NJW) 31/2009: 2288, paragraphs 358, 360.
} 
Where a member of the Council considers that a draft directive as referred to in paragraph 2 [Article 82, paragraph 3] in paragraph 1 or 2 [Article 83, paragraph 3] would affect fundamental aspects of its criminal justice system, it may request that the draft directive be referred to the European Council. In that case, the ordinary legislative procedure shall be suspended. After discussion, and in case of a consensus, the European Council shall, within four months of this suspension, refer the draft back to the Council, which shall terminate the suspension of the ordinary legislative procedure.

Within the same timeframe, in case of disagreement, and if at least nine Member States wish to establish enhanced cooperation on the basis of the draft directive concerned, they shall notify the European Parliament, the Council and the Commission accordingly. In such a case, the authorisation to proceed with enhanced cooperation referred to in Article 20(2) of the Treaty on European Union and Article 329(1) of this Treaty shall be deemed to be granted and the provisions on enhanced cooperation shall apply.

Pursuant to this prescription, the member states have a veto right to prevent an approximation of laws. Article III-271, paragraph 3 of the Treaty establishing a Constitution for Europe ${ }^{76}$ only provided a veto right subject to the condition precedent. ${ }^{77}$ Using the emergency brake, every member state can defend national values against criminalization by European institutions. ${ }^{78}$ Thus, allowing the Union an original law-making competence would foil this right only if national interests could not be saved by national measures. ${ }^{79}$

In the field of procedural criminal law, a restrictive interpretation applies in the same way. ${ }^{80}$

\subsection{THE JUDGMENT'S IMPACT ON MAKING AND APPLYING CRIMINAL LAW}

The Lisbon Judgment not only puts German politics in charge of taking care of European interests but decelerates the unification process. At the same time, the Federal Constitutional Court strengthens the position of the national legislator and legal practitioner. By affirming the principle of conferral, the judgment forms a continuation of the Maastricht doctrine. ${ }^{81}$

\footnotetext{
76 Concerning the Treaty, see the references supra note 10.

77 Martin Heger, supra note 13: 413.

${ }^{78}$ Cf. ibid. : 415.

79 Cf. Volker Stiebig, supra note 5: 489; differing: Martin Heger, supra note 13: 415; q.v. Frank Zieschang, supra note 6: 1313-1314.

80 BVerfGE (Decisions of the Federal Constitutional Court, Vol.) 123, p. $411=$ Neue Juristische Wochenschrift (New legal weekly paper) (NJW) 31/2009: 2288, paragraph 360.

81 Philipp Kiiver, supra note 48: 580; q.v. Jacques Ziller, supra note 39: 67; Mark A. Zöller, supra note 4: 348 .
} 
So, in the area of judicial cooperation in criminal matters, the decision of the Council according to Article 83, paragraph 1 TFEU requires an Act of the German Parliament in terms of Article 23, paragraph 1 of the German Constitution. ${ }^{82}$ That implies, in most cases, a long-winded legislative procedure. Furthermore, within the "emergency brake" action ${ }^{83}$, the Federal Government may act only on the instruction of the Federal Parliament or, as required, of the Federal Council. ${ }^{84}$ Depending on how well the inter-institutional cooperation will work, the restrictions ordered by the Constitutional Court may paralyze decision-making in the Council. ${ }^{85}$ Nevertheless, by this means the court enforces the rule-of-law principle (Article 20, paragraph 3, Article 28, paragraph 1 of the German Constitution) and the principle of democracy (Article 20, paragraph 2 of the German Constitution).

The court, thus, tries to reach a compromise respecting both national and supranational interests while these two levels of making and applying law still do not interlock ${ }^{86}$. At first sight, this may appear to be unprogressive. On closer examination, however, the senate places people at the center, ${ }^{87}$ and in this way respects the socio-cultural relevance of law asserted earlier in this article ${ }^{88}$. According to the so-called emergency brake, the Constitutional Court gives the national legislator and legal practitioner enough scope to consider national cultural norms by demanding only a minimum of legal ethics. As a result, the competences of the Union are interpreted in a restrictive manner in order to save national merits (requirement of protection - Schonungsgebot). ${ }^{89}$

The Constitutional Court relocates decision-making processes at the national level by confirming the principle of conferral and reserving an ultra vires control if legal protection cannot be reached on the European level. ${ }^{90}$ Thus, the court compensates the Union's deficit of democracy ${ }^{91}$ and takes into account the increasing speed of Europeanization devoid of an adequate democratic fundament. Such democratic legitimation has to usher from a self-determined people. ${ }^{92}$ In fact,

82 BVerfGE (Decisions of the Federal Constitutional Court, Vol.) 123, p. $436=$ Neue Juristische Wochenschrift (New legal weekly paper) (NJW) 31/2009: 2295, paragraph 419.

${ }^{83}$ See supra section 2.1.

84 BVerfGE (Decisions of the Federal Constitutional Court, Vol.) 123, p. $436=$ Neue Juristische Wochenschrift (New legal weekly paper) (NJW) 31/2009: 2295, paragraph 418; q.v. Martin Heger, supra note 13: 411.

${ }^{85}$ Cf. Philipp Kiiver, supra note 48: 588.

${ }^{86}$ See introduction.

87 Kai Ambos and Peter Rackow, supra note 2: 399.

${ }^{88}$ See introduction; concurring: Hans-Peter Folz, supra note 3: 427.

89 Martin Böse, supra note 26: 85; cf. BVerfGE (Decisions of the Federal Constitutional Court, Vol.) 123, pp. 410-413 = Neue Juristische Wochenschrift (New legal weekly paper) (NJW) 31/2009: 2288, paragraph 358-2289, paragraph 363; supra note 20; differing: Frank Meyer, supra note 48: 660.

${ }_{90}$ Kai Ambos and Peter Rackow, supra note 2: 399-400.

${ }^{91}$ See Stefan Braum, supra note 2: 418-420; differing: Frank Meyer, supra note 48: 661-663.

92 BVerfGE (Decisions of the Federal Constitutional Court, Vol.) 123, p. $350=$ Neue Juristische Wochenschrift (New legal weekly paper) (NJW) 31/2009: 2271, paragraph 233; q.v. Stefan Braum, supra note 2: 424. 
a European demos already exists. ${ }^{93}$ But, due to the diversity of languages and the various socio-cultural backgrounds of European nations, a "European public" has not yet developed at the present time. ${ }^{94}$ Even if in future a "European public" may be identified, it will consist of different nations so that a "European volition" will represent a cross-section of national interests. ${ }^{95}$

Especially the emphasis on ethic relevance of substantive and procedural criminal law demonstrates that criminal law at large plays a crucial role in the development of a cultural identity for Europeans while Europeanization is steadily proceeding. However, the European unification process must not be advanced at the price of invalidating civic participation. The Lisbon Judgment counterbalances the ahistorical-technocratic impatience of Europeanization especially in the field of criminal law. ${ }^{96}$

After all, the judgment may be seen as a concession to political reality. ${ }^{97}$ Although the Constitutional Court foils the ambitions of the drafters of the Constitutional Treaty to some extent, the restrictions imposed by the court are not unlawful from a European point of view. ${ }^{98}$ The guarantee in perpetuity (Ewigkeitsgarantie) located in Article 79, paragraph 3 of the German Constitution was meant as a steadfast principle by the constitution-drafters. Hence, it must not be touched by European endeavors for unification. ${ }^{99}$

\section{CONCLUSIONS}

In opposition to many skeptics, the Federal Constitutional Court has applied a standard that does not focus on abstract conceptions but, rather, human interests. ${ }^{100}$ It remains doubtful if the foundation of a European federal state would resolve the aspects broached in the judgment. ${ }^{101}$ It is not even certain if such a supranational construct would be appreciated by the member states. ${ }^{102}$

In terms of criminal law, it remains to be discussed whether fields of policy exist which, in any circumstances, have to remain on the operating level of the member states, be it because they cannot be treated appropriately on the European level or because those fields have to be regarded as indispensable to national efficiency. ${ }^{103}$ From the present view, an approximation of criminal laws carries the

\footnotetext{
93 Martin Böse, supra note 26: 84 .

94 Cf. ibid.

95 Differing: Stefan Braum, supra note 2: 424

96 Kai Ambos and Peter Rackow, supra note 2: 399; differing: Frank Meyer, supra note 48: 659-663.

97 Hans-Peter Folz, supra note 3: 431.

${ }^{98}$ Cf. Philipp Kiiver, supra note 48: 585-586, 588.

${ }^{99}$ Cf. Mark A. Zöller, supra note 4: 349.

${ }^{100}$ Kai Ambos and Peter Rackow, supra note 2: 399.

101 Cf. ibid.: 399, note 28.

102 Cf. ibid.

103 Hans-Peter Folz, supra note 3: 427.
} 
inherent danger of legitimate national interests being disregarded and of abolishing the legal monopoly of the member states concerning criminal law ${ }^{104}$ through the back-door ${ }^{105}$. The additional value of a supranational public prosecution could be seen as an abbreviation of the legal process and as a cutback of bureaucracy, caused by a considerably oversized European federalization (Überföderalisierung) ${ }^{106}$. Therefore, with respect to the above-mentioned importance of criminal law for national identity ${ }^{107}$, the forthcoming Europeanization of criminal law should be handled carefully. ${ }^{108}$

In any case, the ongoing Europeanization must not relativize the sovereignty of the member states. ${ }^{109}$ This seems to be the essential message which may be read out of the Lisbon Judgment - regardless of civil law, public law or criminal law questions.

\section{BIBLIOGRAPHY}

1. Ambos, Kai, and Peter Rackow. "Erste Überlegungen zu den Konsequenzen des Lissabon-Urteils des Bundesverfassungsgerichts für das Europäische Strafrecht" (First considerations on the consequences of the Lisbon Judgment of the Federal Constitutional Court for European Criminal Law). Zeitschrift für Internationale Strafrechtsdogmatik (Journal of international criminal law dogmatics) (ZIS) 8-9 (2009): 397-405 //

http://www.zis-online.com/dat/artikel/2009_8-9_346.pdf (accessed December 20, 2010).

2. Beukelmann, Stephan. "Europäisierung des Strafrechts - Die neue strafrechtliche Ordnung nach dem Vertrag von Lissabon" (Europeanization of criminal law - the new criminal law order pursuant to the Lisbon Treaty). Neue Juristische Wochenschrift (New legal weekly paper) (NJW) 29 (2010): 2081-2086.

3. Böse, Martin. "Die Entscheidung des Bundesverfassungsgerichts zum Vertrag von Lissabon und ihre Bedeutung für die Europäisierung des Strafrechts" (The Federal Constitutional Court's Judgment towards the Lisbon Treaty and its relevance to the Europeanization of criminal law). Zeitschrift für Internationale Strafrechtsdogmatik (Journal of international criminal law dogmatics) (ZIS) 2 (2010): 76-91//

\footnotetext{
104 Cf. Martin Heger, supra note 13: 415.

105 Cf. ibid.

106 BVerfGE (Decisions of the Federal Constitutional Court, Vol.) 123, p. $377=$ Neue Juristische Wochenschrift (New legal weekly paper) (NJW) 31/2009: 2279, paragraph 290.

107 See introduction.

108 Cf. Kai Ambos and Peter Rackow, supra note 2: 405.

${ }^{109}$ Cf. ibid.; Volker Stiebig, supra note 5: 492.
} 
http://www.zis-online.com/dat/artikel/2010_2_407.pdf (accessed December 20, 2010).

4. Braum, Stefan. "Europäisches Strafrecht im administrativen Rechtsstil. Zur kriminalpolitischen Konzeption des EU-Grünbuchs Europäische Staatsanwaltschaft" (European criminal law in an administrative style of making and applying law. On the crimino-political conception of the Green Paper "European Public Prosecutor's Office"). Zeitschrift für Rechtspolitik (Journal of legal policy) (ZRP) 12 (2002): 508-514.

5. Braum, Stefan. "Europäisches Strafrecht im Fokus konfligierender Verfassungsmodelle. Stoppt das Bundesverfassungsgericht die europäische Strafrechtsentwicklung?" (European criminal law in the focus of conflicting constitutional systems. Will the Federal Constitutional Court stop the European development in criminal law matters?). Zeitschrift für Internationale Strafrechtsdogmatik (Journal of international criminal law dogmatics) (ZIS) 89 (2009): 418-426//

http://www.zis-online.com/dat/artikel/2009_8-9_348.pdf (accessed December 20, 2010).

6. Cancio Meliá, Manuel. "Rechtsvergleichende Bemerkungen zum Allgemeinen Teil des portugiesischen Strafgesetzbuches aus spanisch-deutscher Sicht" (Comparative law comments on the general part of the Portuguese criminal code from a Spanish-German view). Goltdammer's Archiv für Strafrecht (Goltdammer's archive of criminal law) (GA) 3 (1998): 118-123.

7. Dehne-Niemann, Jan. "'Nie sollst Du mich befragen' - Zur Behandlung des Rechts zur Konfrontation mitbeschuldigter Belastungszeugen (Art. 6 Abs. 3 lit. d EMRK) durch den BGH. Zugleich Besprechung von BGH 4 StR 461/08 Beschluss vom 9. Juni 2009, HRRS 2009 Nr. 803 und EGMR HRRS 2009 Nr. 459" ("Never you shall interrogate me" - Upon dealing with the right of confrontation of other accused witnesses of the prosecution (Article 6, paragraph 3(d) ECHR) by the Federal Court of Justice. At the same time a review of the Federal Court of Justice's adjudication issued on June 9, 2009 4 StR 461/08 -, HRRS 2009 No. 803 and of ECtHR HRRS 2009 No. 459). Online-Zeitschrift für Höchstrichterliche Rechtsprechung im Strafrecht (Online journal of high court decisions in criminal law) (HRRS) 4 (2010): 189-207 // http://www.hrr-strafrecht.de/hrr/archiv/10-04/hrrs-4-10.pdf (accessed December 20, 2010).

8. Folz, Hans-Peter. "Karlsruhe, Lissabon und das Strafrecht - ein Blick über den Zaun" (Karlsruhe, Lisbon and criminal law - getting an impression of the Federal Constitutional Court's jurisdiction). Zeitschrift für Internationale 
Strafrechtsdogmatik (Journal of international criminal law dogmatics) (ZIS) 89 (2009): 427-431//

http://www.zis-online.com/dat/artikel/2009_8-9_349.pdf (accessed December 20, 2010).

9. Hauck, Pierre. "Funktionen und Grenzen des Einflusses der Strafrechtsvergleichung auf die Strafrechtsharmonisierung in der Europäischen Union" (Functions and limitations of the impact of comparative criminal law on the approximation of laws in the European Union): 255-273. In: Susanne Beck, Christoph Burchard, and Bijan Fateh-Moghadam, eds. Strafrechtsvergleichung als Problem und Lösung. Kolloquium am 30. und 31. Oktober 2009 an der Juristischen Fakultät der Julius-Maximilians-Universität Würzburg (Comparative criminal law both as problem and as solution. Congress on October 30 and 31, 2009 at the faculty of law of the JuliusMaximilians-University Würzburg). Baden-Baden: Nomos, 2010.

10. Hecker, Bernd. "Der Vertrag von Lissabon und das Europäische Strafrecht" (The Lisbon Treaty and European Criminal Law). Iurratio 2 (2009): 81-85 // http://www.iurratio.de/zeitschrift/ausgabe-22009/100 (accessed December 20, 2010).

11. Hecker, Bernd. Europäisches Strafrecht (European criminal law). $3^{\text {rd }}$ edition. Berlin, Heidelberg: Springer, 2010.

12. Heger, Martin. "Perspektiven des Europäischen Strafrechts nach dem Vertrag von Lissabon. Eine Durchsicht des (wohl) kommenden EU-Primärrechts vor dem Hintergrund des Lissabon-Urteils des BVerfG vom 30.6.2009" (Perspectives of European Criminal Law pursuant to the Lisbon Treaty. A review of the (probably) coming EU primary law against the background of the Lisbon Judgment of the Federal Constitutional Court issued on June 30, 2009). Zeitschrift für Internationale Strafrechtsdogmatik (Journal of international criminal law dogmatics) (ZIS) 8-9 (2009): 406-417 // http://www.zis-online.com/dat/artikel/2009_8-9_347.pdf (accessed December 20, 2010).

13. Keijzer, Nico, and Elies Van Sliedregt, eds. The European Arrest Warrant in Practice. Den Haag: T.M.C. Asser Press, 2009.

14. Kiiver, Philipp. "The Lisbon Judgment of the German Constitutional Court: A Court-Ordered Strengthening of the National Legislature in the EU." European Law Journal 16/5 (2010): 578-588 // http://onlinelibrary.wiley.com/doi/10.1111/j.1468-0386.2010.00523.x/pdf (accessed December 20, 2010). 
15. Manacorda, Stefano. "Die allgemeine Lehre von der Straftat in Frankreich: Besonderheiten oder Lücken in der französischen Strafrechtswissenschaft?" (The general doctrine of criminal action in France: specific characteristics or desideratums in French penologic science?). Goltdammer's Archiv für Strafrecht (Goltdammer's archive of criminal law) (GA) 3 (1998): 124-126.

16. The Members of the Federal Constitutional Court, eds. Decisions of the Federal Constitutional Court (BVerfGE). Vol. 123. Tübingen: Mohr Siebeck, 2010.

17. Meyer, Frank. "Die Lissabon-Entscheidung des BVerfG und das Strafrecht" (The Lisbon Judgment of the Federal Constitutional Court and criminal law). Neue Zeitschrift für Strafrecht (New Journal of criminal law) (NStZ) 12 (2009): 657-663.

18. Nürnberger, Silke. "Die zukünftige Europäische Staatsanwaltschaft - Eine Einführung" (The future European Public Prosecutor's Office - An introduction). Zeitschrift für das Juristische Studium (Journal of law studies) (ZJS) 5 (2009): 494-505 // http://www.zjs-online.com/dat/artikel/2009_5_225.pdf (accessed December 20, 2010).

19. Observatório Permanente da Justiça Portuguesa, Centro de Estudos Sociais, Colégio de S. Gerónimo (Permanent committee of the Portuguese justice, centre of social studies, S. Gerónimo College), ed. The European Arrest Warrant in Law and in Practice: A Comparative Study for the Consolidation of the European Law-Enforcement Area. Coimbra: 2010 // http://opj.ces.uc.pt/pdf/EAW_Final_Report_Nov_2010.pdf (accessed December 20, 2010).

20. Prittwitz, Cornelius. "Nachgeholte Prolegomena zu einem künftigen Corpus Iuris Criminalis für Europa" (Made up prolegomena on a future Corpus Iuris Criminalis for Europe). Zeitschrift für die gesamte Strafrechtswissenschaft (Journal of the whole penologic sciences) (ZStW) 113/4 (2001): 774-799.

21. Satzger, Helmut. Die Europäisierung des Strafrechts. Eine Untersuchung zum Einfluss des Europäischen Gemeinschaftsrechts auf das deutsche Strafrecht (The Europeanization of criminal law. A study of the impact of the European Community law on German criminal law). Köln: Carl Heymanns, 2001.

22. Satzger, Helmut. Internationales und Europäisches Strafrecht. Strafanwendungsrecht/Europäisches Straf- und Strafverfahrensrecht/ Völkerstrafrecht (International and European criminal law. Law regulating the implementation of penalty/European substantive and procedural criminal law/international criminal law). $4^{\text {th }}$ edition. Baden-Baden: Nomos, 2010. 
23. Silva Sánchez, Jesús-María. Die Expansion des Strafrechts. Kriminalpolitik in postindustriellen Gesellschaften (The expansion of criminal law. Criminal policy in post-industrial societies). Frankfurt am Main: Vittorio Klostermann, 2003.

24. Sinn, Arndt, and Liane Wörner. "The European Arrest Warrant and Its Implementation In Germany - Its Constitutionality, Laws and Current Developments". Zeitschrift für Internationale Strafrechtsdogmatik (Journal of international criminal law dogmatics) (ZIS) 5 (2007): 204-220 //

http://www.zis-online.com/dat/artikel/2007_5_135.pdf (accessed December 20, 2010).

25. Sommer, Ulrich. "Annotation of the adjudication of the Federal Court of Justice issued on March 17, 2010 - 2 StR 397/09 -". Strafverteidiger Forum (Forum of criminal defence lawyers) (StraFo) 7 (2010): 284-285.

26. Stiebig, Volker. Vollstreckungsverzicht und Grundfreiheiten. Ein Beitrag zur Entwicklung des Europäischen Strafrechts (Desisting from enforcement and fundamental freedoms. A contribution to the development of European Criminal Law). Frankfurt am Main: Lang, 2003.

27. Stiebig, Volker. "Strafrechtsetzungskompetenz der Europäischen Gemeinschaft und Europäisches Strafrecht: Skylla und Charybdis einer europäischen Odyssee?" (The European Community's competence of making criminal law and European Criminal Law: Skylla and Charybdis of a European odyssey?). Europarecht (European law) (EuR) 4 (2005): 466-493 // http://www.europarecht.nomos.de/fileadmin/eur/doc/EuR_05_04.pdf (accessed December 20, 2010).

28. Stiebig, Volker. "Annotation of the adjudication of the Federal Court of Justice issued on March 17, 2010 - 2 StR 397/09 -". Juristische Rundschau (Law review) (JR) 4 (2011): 170-177.

29. Suárez González, Carlos. "Rechtsvergleichende Bemerkungen zum Allgemeinen Teil des neuen spanischen Strafgesetzbuches" (Comparative law comments on the general part of the new Spanish criminal code). Goltdammer's Archiv für Strafrecht (Goltdammer's archive of criminal law) (GA) 3 (1998): 111-117.

30. Suhr, Oliver. "Strafrechtsharmonisierung in der Europäischen Union. Neue Grenzziehungen und zusätzliche Kontrollaufträge" (Approximation of criminal laws in the European Union. New delineations and additional mandates for scrutiny). Zeitschrift für europarechtliche Studien (Journal of European law studies) (ZEuS) 1 (2008): 45-80. 
31. Tiedemann, Klaus. "Die Europäisierung des Strafrechts" (The Europeanization of criminal law): 133-160. In: Karl F. Kreuzer, Dieter H. Scheuing, and Ulrich Sieber, eds. Die Europäisierung der mitgliedstaatlichen Rechtsordnungen in der Europäischen Union (The Europeanization of the member states' legal systems in the European Union). Baden-Baden: Nomos, 1997.

32. Tiedemann, Klaus. "Lehren von der Straftat im Allgemeinen Teil der Europäischen Rechtssysteme - Überlegungen zur Strafrechtsangleichung in Europa -/Einleitung: Re-Europäisierung des Strafrechts versus Nationalismus der (deutschen) Strafrechtslehre" (Doctrines of criminal action in the general part of European legal systems - considerations on the approximation of criminal laws in Europe -/Introduction: Re-Europeanization of criminal law versus nationalism of (German) criminal law dogmatics). Goltdammer's Archiv für Strafrecht (Goltdammer's archive of criminal law) (GA) 3 (1998): 107110.

33. Vogel, Joachim. "Elemente der Straftat: Bemerkungen zur französischen Straftatlehre und zur Straftatlehre des common law" (Elements of criminal action: comments on the French doctrine of criminal action and on the common law doctrine of criminal action). Goltdammer's Archiv für Strafrecht (Goltdammer's archive of criminal law) (GA) 3 (1998): 127-150.

34. Wessels, Johannes, and Werner Beulke. Strafrecht Allgemeiner Teil. Die Straftat und ihr Aufbau (The general part of criminal law. Criminal action and the way of analyzing it). 40 th edition. Heidelberg: C.F. Müller, 2010.

35. Wörner, Liane. The Effectiveness of Wiretapping and Electronic Surveillance to Fight against Terrorism. A comparative analysis between the United States and Germany. Baden-Baden: Nomos, 2004.

36. Zieschang, Frank. "Akzeptanz Europäischen Strafrechts?" (Acceptance of European criminal law?): 39-50. In: Gerhard Hohloch, ed. Wege zum Europäischen Recht (Avenues to European law). Baden-Baden: Nomos, 2002.

37. Zieschang, Frank. "Der Einfluss der Europäischen Union auf das deutsche Strafrecht - Eine Bestandsaufnahme -" (The impact of the European Union on German criminal law - An appraisal -): 1303-1319. In: Ulrich Sieber, Gerhard Dannecker, Urs Kindhäuser, Joachim Vogel, and Tonio Walter, eds. Strafrecht und Wirtschaftsstrafrecht - Dogmatik, Rechtsvergleich, Rechtstatsachen -. Festschrift für Klaus Tiedemann zum 70. Geburtstag (Criminal law and law relating to economic offenses - dogmatics, comparative law analysis, legal facts -. Festschrift for Klaus Tiedemann on the occasion of his $70^{\text {th }}$ birthday). Köln, Berlin, Bonn, München: Carl Heymanns, 2008.

38. Zila, Josef. "Akzeptanz des Europäischen Strafrechts in Schweden" 
(Acceptance of European Criminal Law in Sweden): 63-72. In: Gerhard Hohloch, ed. Wege zum Europäischen Recht (Avenues to European law). Baden-Baden: Nomos, 2002.

39. Ziller, Jaques. "The German Constitutional Court's Friendliness towards European Law. On the Judgment of Bundesverfassungsgericht over the Ratification of the Treaty of Lisbon." European Public Law 16/1 (2010): 53-73 //

http://www.kluwerlawonline.com/document.php?id=EURO2010004\&mode $=a b$ stract\& (accessed December 20, 2010).

40. Ziller, Jaques. "Zur Europarechtsfreundlichkeit des deutschen Bundesverfassungsgerichtes. Eine ausländische Bewertung des Urteils des Bundesverfassungsgerichtes zur Ratifikation des Vertrages von Lissabon" [German version of number 39]. Zeitschrift für öffentliches Recht (ZÖR) 65 (2010): 157-176//

http://www.springerlink.com/content/v0615w58513238g2/fulltext.pdf (accessed December 20, 2010).

41. Zöller, Mark A. "Europäische Strafgesetzgebung" (European criminal law legislation). Zeitschrift für Internationale Strafrechtsdogmatik (Journal of international criminal law dogmatics) (ZIS) 7 (2009): 340-349 // http://www.zis-online.com/dat/artikel/2009_7_335.pdf (accessed December 20, 2010).

42. Zuleeg, Manfred. "Der Beitrag des Strafrechts zur Europäischen Integration" (The contribution of criminal law to European integration): 41-60. In: Ulrich Sieber, ed. Europäische Einigung und Europäisches Strafrecht. Beiträge zum Gründungssymposium der Vereinigung für Europäisches Strafrecht e.V. (European unification and European Criminal Law. Papers written on the occasion of the symposium to celebrate the foundation of the incorporated Association for European Law). Köln, Berlin, Bonn, München: Carl Heymanns, 1993. 